\title{
Trichomonascus apis sp. nov., a heterothallic yeast species from honeycomb
}

\author{
Gábor Péter, Judit Tornai-Lehoczki and Dénes Dlauchy
}

Correspondence

Gábor Péter

gabor.peter@uni-corvinus.hu
National Collection of Agricultural and Industrial Microorganisms (NCAIM), Corvinus University of Budapest, Faculty of Food Sciences, Somlói út 14-16, H-1118 Budapest, Hungary

\begin{abstract}
Four strains of a novel heterothallic yeast species were isolated from pollen-storing cells of a honeycomb of honeybee (Apis mellifera) in Hungary. Analysis of the D1/D2 domain of the largesubunit (26S) rRNA gene sequences placed the strains in the Trichomonascus clade. The four strains share identical D1/D2 sequences and differ by 24 substitutions and nine indels from the genetically most closely related species, Blastobotrys attinorum. The name Trichomonascus apis sp. nov. is proposed for the novel species. The carbon-source assimilation spectrum of $T$. apis sp. nov. is rather broad. Unlike $B$. attinorum, it assimilates sucrose, trehalose, D-glucuronate and succinate and does not grow at $37{ }^{\circ} \mathrm{C}$, thus enabling the two taxa to be distinguished. The type and isotype strains of Trichomonascus apis are NCAIM Y.01848 ${ }^{\top}\left(=\mathrm{CBS} 10922^{\top}=\mathrm{NRRL} Y\right.$ $\left.48475^{\mathrm{T}}\right)$ and NCAIM Y.01849 ${ }^{\mathrm{T}}\left(=\mathrm{CBS} 10923^{\mathrm{IT}}=\right.$ NRRL $\left.\mathrm{Y}-48476^{\mathrm{IT}}\right)$, respectively.
\end{abstract}

Trichomonascus mycophagus was described by Jackson (1947). The species appeared to be mycoparasitic on Corticium confluens growing on the bark of Abies balsamea. Jackson was unable to cultivate T. mycophagus on laboratory media; however, the attempt was made several months after the collection of the fungal material. $T$. mycophagus is only known from dried herbarium collections (Malloch \& de Hoog, 1998). Jackson (1947) placed the genus in the family Aspergillaceae. Benny \& Kimbrough (1980) were of the opinion that the taxonomic relationship of this fungus is uncertain and fresh material would be needed to determine whether Trichomonascus is related to any other known taxon. Malloch \& de Hoog (1998) listed Trichomonascus among endomycete-like genera. The second Trichomonascus species, Trichomonascus rutilus, was described from two herbarium specimens collected from wood in 1961 and 1967 in Denmark (Hauerslev, 1987). The type material of $T$. rutilus is not axenic. Besides $T$. rutilus, which exhibits clear ascomycetous characters, spores and basidia similar to those of Radulomyces confluens were found in the type material. Hauerslev (1987) concluded that $T$. rutilus may be a parasite, like $T$. mycophagus. Kurtzman (2004) described Trichomonascus petasosporus, the third species of the genus. T. petasosporus is a culturable, heterothallic yeast species of the order Saccharomycetales and the three strains mentioned in the description were isolated from insect frass, collected from different trees in the USA. Kurtzman's efforts to isolate DNA from the herbarium specimen of $T$. mycophagus, the type species of the genus, were

The GenBank/EMBL/DDBJ accession number for the D1/D2 domain of the 26S rRNA gene sequence of strain NCAIM Y.01848 ${ }^{\top}$ (=CBS $10922^{\top}=$ NRRL $Y-48475^{\top}$ ) is EU790643. unsuccessful, preventing him from performing a genetic comparison of the two taxa. However, he argued that the nearly identical unique morphology of the sexual states of T. mycophagus and T. petasosporus leaves little doubt that they are closely related. A multigene phylogenetic analysis revealed that $T$. petasosporus is related closely to Stephanoascus ciferrii, the type species of the genus Stephanoascus (Kurtzman \& Robnett, 2007). As Trichomonascus H. S. Jackson (1947) has taxonomic priority over Stephanoascus M. Th. Smith, van der Walt \& E. Johannsen (1976), S. ciferrii and the related species Stephanoascus farinosus were transferred to the genus Trichomonascus (Kurtzman \& Robnett, 2007). Similarly, the same authors transferred most of the anamorphic species of the Trichomonascus clade to the genus Blastobotrys von Klopotek (1967), which has taxonomic priority over Sympodiomyces Fell \& Statzel (1971) and Arxula van der Walt, M. Th. Smith \& Y. Yamada (1990). Since then, the Trichomonascus clade has been expanded considerably by the description of seven novel Blastobotrys species (Middelhoven \& Kurtzman, 2007; Kurtzman, 2007). In this paper, we report the isolation of four yeast strains representing haploid mating types of a novel Trichomonascus species, and propose a novel species with the name Trichomonascus apis sp. nov. to accommodate these strains.

The four strains used in this study (Table 1) were isolated on rose-bengal chloramphenicol (RBC) agar from pollenstoring cells of the same mouldy honeycomb of honeybee (Apis mellifera) in Hungary in 1994. Strains representing different colony morphologies were picked, purified and characterized by using standard methods described by Yarrow (1998). Sexual reactivity was studied by mixing 
Table 1. Trichomonascus apis strains used in this study

CBS, Centraalbureau voor Schimmelcultures, Utrecht, the Netherlands; NCAIM, National Collection of Agricultural and Industrial Microorganisms, Budapest, Hungary; NRRL, Agricultural Research Service Culture Collection, National Center for Agricultural Utilization Research, Peoria, IL, USA.

\begin{tabular}{|lll|}
\hline Strain & \multicolumn{1}{c|}{ Source of isolation } & Mating type \\
\hline NCAIM Y. $01848^{\mathrm{T}}\left(=\right.$ CBS $10922^{\mathrm{T}}=$ NRRL Y-48475 $5^{\mathrm{T}}$ & Mouldy honeycomb, Hungary & $\mathrm{h}^{\mathrm{T}}$ \\
NCAIM Y.01849 $9^{\mathrm{IT}}\left(=\mathrm{CBS} 10923^{\mathrm{IT}}=\right.$ NRRL Y-48476 $\left.6^{\mathrm{IT}}\right)$ & Mouldy honeycomb, Hungary & $\mathrm{h}^{\mathrm{I}}$ \\
NCAIM Y.01850 & Mouldy honeycomb, Hungary & $\mathrm{h}^{\mathrm{T}}$ \\
NCAIM Y.01851 & Mouldy honeycomb, Hungary & $\mathrm{h}^{\mathrm{I}}$ \\
\hline
\end{tabular}

actively growing cultures of the four investigated strains on acetate ( $1.4 \%$ sodium acetate, $0.04 \%$ glucose), cornmeal (CM), potato-glucose (PDA), $2 \%$ malt extract, glucosepeptone-yeast extract (GPY), yeast extract-malt extract (YM) and V8 agars. The mixture was incubated at 15 and $25{ }^{\circ} \mathrm{C}$ and examined regularly by microscopy up to 21 days. Mating types were determined by pairwise mixing of actively growing cultures of the investigated strains in all possible combinations on $\mathrm{CM}$ agar at $15{ }^{\circ} \mathrm{C}$. The D1/D2 domain of the large-subunit (26S) rRNA gene from selected strains was sequenced as described by Kurtzman \& Robnett (1998). A sequence-similarity search was performed against GenBank by using the BLAST 2.2.18 database-search program (Altschul et al., 1997). The sequences generated during this study, along with sequences of related species retrieved from GenBank, were aligned and a phylogenetic tree was constructed by the neighbour-joining method (Saitou \& Nei, 1987) using the CLUSTAL_x 1.81 program (Thompson et al., 1997). Bootstrap support for the tree was determined from 1000 replications.

The dominant yeast strain recovered from the pollen stored in the investigated honeycomb was identified as Candida magnoliae. It was accompanied by two minor ones, represented by only a few colonies. One of them was identified as Zygosaccharomyces rouxii, whilst the other proved to be a thus-far-undescribed species. Four strains of this novel species were isolated. Analysis of the D1/D2 large-subunit rRNA gene sequences placed them in the Trichomonascus clade (Fig. 1). The phylogenetic tree exhibits an arrangement of the included species similar to that of the tree derived from the analysis of multigene sequences by Kurtzman \& Robnett (2007). The four strains share identical D1/D2 sequences (the GenBank accession number of strain NCAIM Y. $01848^{\mathrm{T}}$ is indicated on the phylogenetic tree depicted in Fig. 1) and differ significantly from the genetically most closely related species, $B$. (Sympodiomyces) attinorum. Twenty-four substitutions and nine indels were detected in the D1/D2 region, indicating that the two taxa are phylogenetically distinct. As the novel species clusters near to the known Trichomonascus species and sexual reproduction was observed, we assign it to the genus Trichomonascus.

The isolates of T. apis represented opposite mating types. The type strain $\left(\mathrm{Y} .01848^{\mathrm{T}}\right)$ was designated $\mathrm{h}^{\mathrm{T}}$ and the isotype strain $\left(\mathrm{Y} .01849^{\mathrm{IT}}\right)$ as $\mathrm{h}^{\mathrm{I}}$, whilst the mating types of the other two investigated strains were defined in reference to them (Table 1). Sexual reproduction of this species resembles that of the former Stephanoascus species, rather than the peculiar manner of ascospore formation of $T$. mycophagus, the type species of the genus, or the recently described T. petasosporus. The two mating types of the novel species show some morphological dimorphism: mating type $\mathrm{h}^{\mathrm{T}}$ produces white/cream colonies on $5 \%$ malt extract agar after 3 days at $25{ }^{\circ} \mathrm{C}$. Its filamentous character is more pronounced and it produces fewer blastoconidia. Mating type $h^{\mathrm{I}}$ produces cream-coloured colonies under the same conditions, its filamentous character is less pronounced and it produces more blastoconidia.

The four strains of T. apis were isolated from pollen-storing cells of a mouldy honeycomb. The ability of the strains to grow at reduced water activity [with $50 \%$ glucose and with 10 or $16 \%(\mathrm{w} / \mathrm{v}) \mathrm{NaCl}$ ] seems to be in accord with the conditions provided by the source of isolation. However, subsequent efforts to isolate additional strains of the species from the same (honeycomb with pollen) or related (honey with or without honeycomb, pollen collected by honeybees, dead honeybees) sources were unsuccessful. The genetically most closely related species, B. (Sympodiomyces) attinorum, was also recovered from an insect-associated habitat: the four strains of that species were isolated from laboratory nests of the leaf-cutting ant (Atta sexdens) in Brazil (Carreiro et al., 2004). In contrast, Blastobotrys (Sympodiomyces) parvus, which is also related to T. apis, may be endemic to marine waters (Statzell-Tallman \& Fell, 1998). The carbon-source assimilation spectrum of T. apis is rather broad. Except for inulin, methanol and saccharate, all investigated carbon sources were assimilated (some of them weakly and/or slowly or variably). It can be separated easily from B. attinorum by several standard physiological characteristics, e.g. by assimilation of sucrose, trehalose, D-glucuronate and succinate. In addition, B. attinorum grows at $37{ }^{\circ} \mathrm{C}$ (Carreiro et al., 2004), whereas growth of the T. apis strains is already weak and variable at $30{ }^{\circ} \mathrm{C}$.

\section{Latin diagnosis of Trichomonascus apis Péter, Tornai-Lehoczki \& Dlauchy sp. nov.}

In extracto malti post dies tres in $25{ }^{\circ} \mathrm{C}$ annulus incompletus et sedimentum floccosum formantur, pellicula non formantur. 


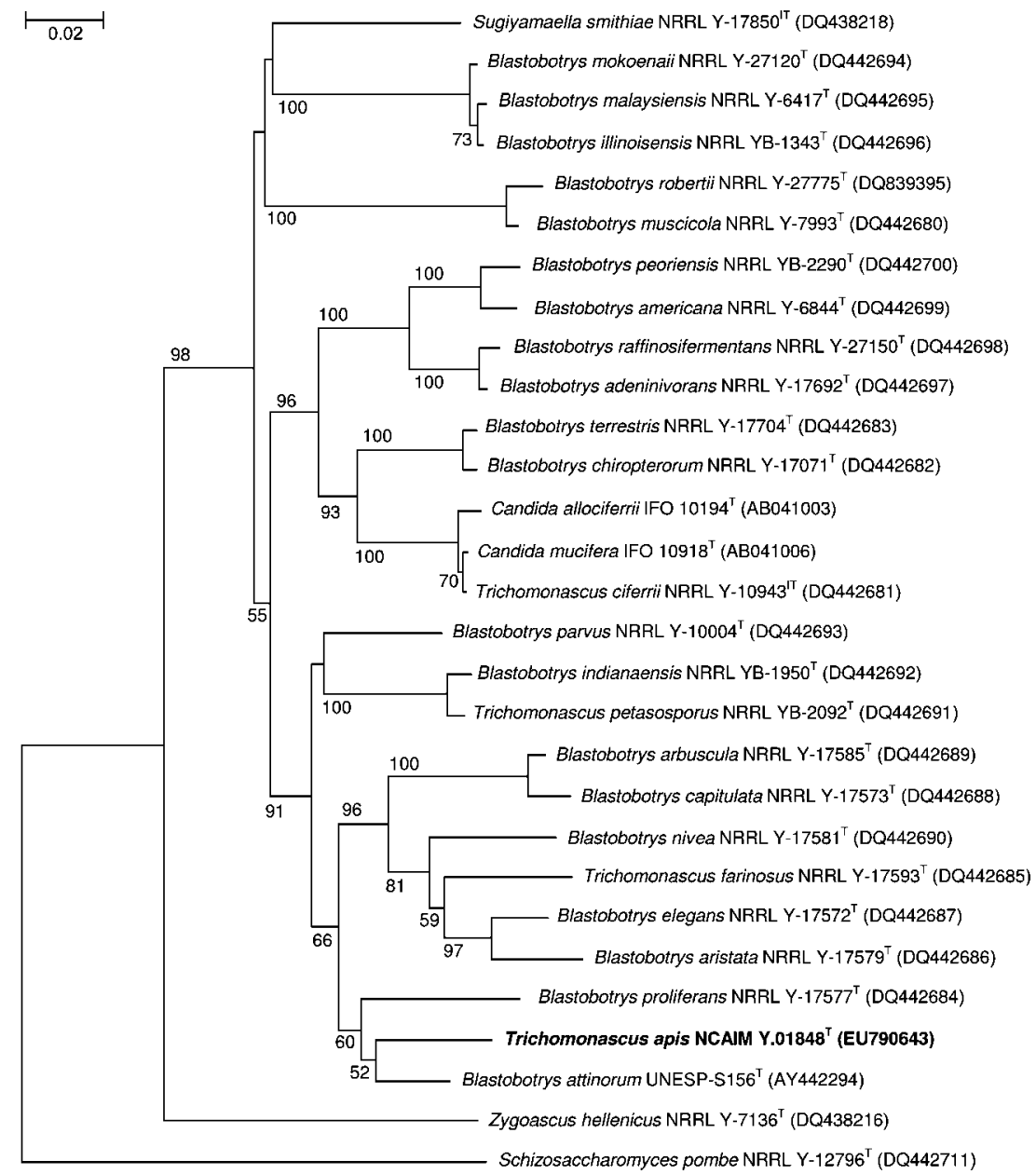

Fig. 1. Phylogenetic tree showing the placement of Trichomonascus apis and some related species based on analysis of the D1/ D2 domain of the large-subunit (26S) rRNA gene. Sequences not generated during this study were obtained from GenBank; accession numbers are shown in parentheses. The tree was constructed by neighbour-joining analysis of aligned sequences. Schizosaccharomyces pombe was used as an outgroup. Numbers at nodes indicate percentages of bootstrap sampling from 1000 replications. Bar, 0.02 sequence divergence.
Hyphae septatae, ramosae $(1.5-3.5 \mu \mathrm{m})$ et blastoconidia ellipsoideae, ovoideae vel elongatae $(2.5-5.0 \times 5-10 \mu \mathrm{m})$ formantur. In agaro malti post dies tres in $25{ }^{\circ} \mathrm{C}$ cultura est offirmata, membranacea, cremea vel alba, pilosa, et opaca. Centrum coloniae sublatum est. In agaro Zea maydis confecto post dies 7 in $25{ }^{\circ} \mathrm{C}$ mycelium verum formantur. Species heterothallica. Asci subglobosae, ellipsoideae, obpyriformae aut obclavatae, cellula apicali coronata, 1-4 ascosporas ellipsoideas, non liberas habent. D-Glucosum (lente) et D-galactosum (lente) fermentantur. Maltosum, sucrosum, lactosum, raffinosum et trehalosum non fermentantur. D-Glucosum, D-galactosum, Lsorbosum, D-glucosaminum, N-acetyl-D-glucosaminum, Dribosum, D-xylosum, L-arabinosum, D-arabinosum (lente), L-rhamnosum, sucrosum, maltosum, trehalosum, $\alpha$-methyl-Dglucosidum, cellobiosum, salicinum (exigue, lente), arbutinum (lente, variabile), melibiosum (lente), lactosum (lente, variabile), raffinosum (lente, variabile), melezitosum (valde exigue, variabile), amylum solubile, glycerolum, meso-erythritolum, ribitolum, xylitolum, L-arabinitolum, D-glucitolum, D-mannitolum, galactitolum, myo-inositolum, glucono- $\delta$-lactonum (lente, variabile), 2-ketogluconicum (variabile), D-gluconicum, D-glucuronicum, D-galacturonicum (lente), DL-lactatum (lente), succinatum, citratum (lente), ethanolum, propane- 1,2-diolum (lente), butane-2,3-diolum (exigue, lente, variabile) et hexadecanum (lente, variabile) assimilantur, at non inulinum, methanolum et saccharatum. Ethylaminum hydrochloricum, lysinum, cadaverinum dihydrochloricum et glucosaminum assimilantur, at non kalium nitricum, natrium nitrosum, creatinum, creatininum, imidazolum. Materia amyloidea iodophila non formantur. Vitamina externa crescentiae sunt necessaria. Crescere potest (variabile) in $30{ }^{\circ} \mathrm{C}$, at non in $35^{\circ} \mathrm{C}$. In agaro extracto fermenti confecto 50 partes glucosi per centum crescit, at non in agaro extracto fermenti confecto 60 partes glucosi per centum. Parte una cycloheximidi per mille crescit. Ureum non finditur. Diazonium caeruleum B est negativum. Typus stirps NCAIM Y.01848 $\left(=\mathrm{CBS} 10922^{\mathrm{T}}=\mathrm{NRRL} \mathrm{Y}-48475^{\mathrm{T}}\right)$. Isolata ex favo apis, Hungaria. Isotypus stirps NCAIM Y.01849 ${ }^{\mathrm{IT}}$ (=CBS $10923^{\mathrm{IT}}$ $=\mathrm{NRRL} Y-48476^{\mathrm{IT}}$ ). Isolata ex favo apis, Hungaria.

\section{Description of Trichomonascus apis Péter, Tornai-Lehoczki \& Dlauchy sp. nov.}

Trichomonascus apis (a'pis. L. gen. fem. sing. n. apis of a bee, referring to the honeybee-associated isolation source of the investigated strains). 


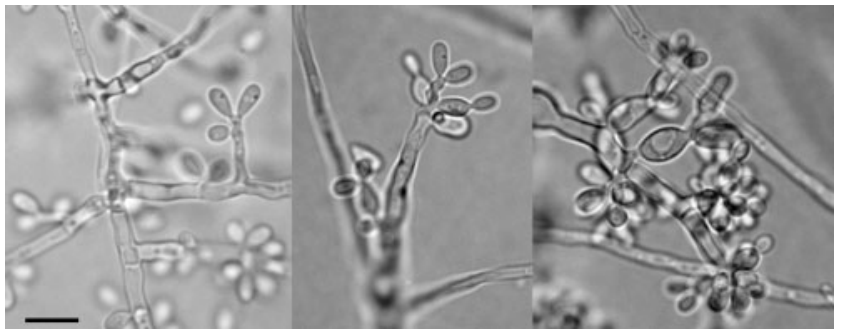

Fig. 2. Septate hyphae, blastoconidia and sympodia of Trichomonascus apis NCAIM Y.01848 ${ }^{\top}$ (malt extract, 3 days, $\left.25^{\circ} \mathrm{C}\right)$. Bar, $10 \mu \mathrm{m}$.

In $5 \%$ malt extract after 3 days at $25{ }^{\circ} \mathrm{C}$, growth mainly consists of clusters of true, branching hyphae (1.5-3.5 $\mu \mathrm{m}$ in diameter). The hyphae give rise to ellipsoid, ovoid or elongated blastoconidia $(2.5-5.0 \times 5-10 \mu \mathrm{m})$. Conidia are produced singly or in small clusters, mostly on denticles, pedicels, protuberances or sympodia (Fig. 2). Incomplete ring and loose flocculent sediment are present. On $5 \%$ malt extract agar after 3 days at $25{ }^{\circ} \mathrm{C}$, the streak culture is tough, membranous, moderately raised, cream-coloured or white, fine-hairy and dull. On slide culture with CM agar after 7 days at $25{ }^{\circ} \mathrm{C}$, the growth is snow-white and filamentous; septate hyphae and blastoconidia are formed (Fig. 3). The species is heterothallic. Individual strains at 15 or $25{ }^{\circ} \mathrm{C}$ or a mixture of strains at $25{ }^{\circ} \mathrm{C}$ formed no ascospores after 3 weeks incubation on acetate, CM, PDA, $2 \%$ malt extract, GPY, YM or V8 agars. However, when compatible mating types were mixed, good ascosporulation was observed on $\mathrm{CM}$ agar at $15{ }^{\circ} \mathrm{C}$ within 2 weeks. Conjugation of hyphal cells preceding ascus formation was observed in the cases of some asci. Asci are persistent and variable in shape even in the same cross (Fig. 4). They are subglobose, ellipsoid, obpyriform and obclavate, measure $4-8 \times 6-13 \mu \mathrm{m}$ and bear a cylindrical or conical apical cell, from which buds sometimes arise. Rarely, the apical cell is divided by a transversal septum. One to four ellipsoid ascospores are formed per ascus. One side of the

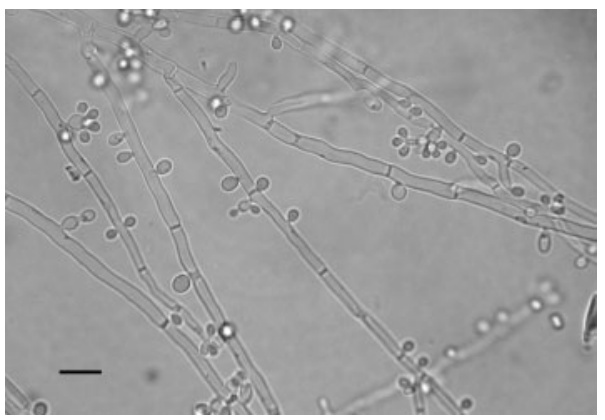

Fig. 3. Septate hyphae and blastoconidia of Trichomonascus apis NCAIM Y.01848 ${ }^{\top}$ (CM agar, 7 days, $\left.25^{\circ} \mathrm{C}\right)$. Bar, $10 \mu \mathrm{m}$.

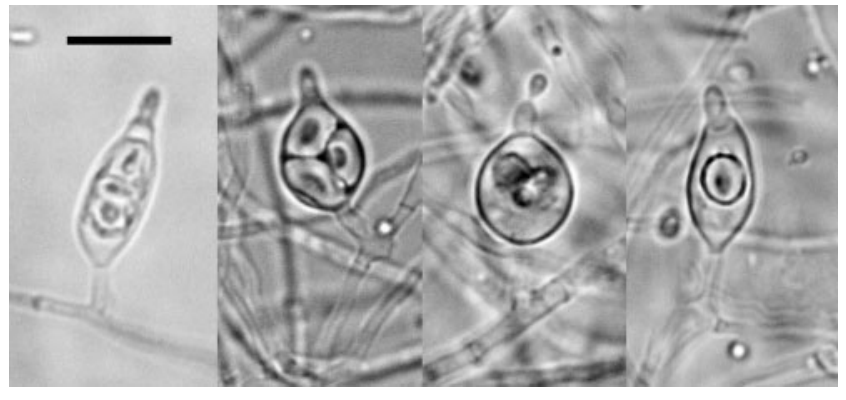

Fig. 4. Ascosporulating culture of Trichomonascus apis NCAIM Y.01848 ${ }^{\top} \times$ NCAIM Y.01849 ${ }^{\mathrm{T}}$ (CM agar, $14-16$ days, $\left.15{ }^{\circ} \mathrm{C}\right)$. Bar, $10 \mu \mathrm{m}$.

ascospores is often depressed; their lower surface is sometimes even concave and may contain a refractive droplet. D-Glucose (slow) and D-galactose (weak and slow) are fermented; maltose, sucrose, lactose, raffinose and $\alpha, \alpha$-trehalose are not fermented. Carbon compounds Dglucose, D-galactose, L-sorbose, D-glucosamine, $N$-acetyl-Dglucosamine, D-ribose, D-xylose, L-arabinose, D-arabinose (slow or weak slow), L-rhamnose, sucrose, maltose, $\alpha, \alpha$ trehalose, methyl $\alpha$-D-glucoside, cellobiose, salicin (weak, slow or very weak, slow), arbutin (slow and variable), melibiose (slow or weak, slow), lactose (slow and variable), raffinose (slow and variable), melezitose (very weak and variable), starch, glycerol, meso-erythritol, ribitol, xylitol, Larabinitol, D-glucitol, D-mannitol, galactitol, myo-inositol, glucono- $\delta$-lactone (slow and variable), 2-keto-D-gluconate (variable), D-gluconate, D-glucuronate, D-galacturonate (slow or weak, slow), DL-lactate (slow or very weak, slow), succinate, citrate (slow), ethanol, propane 1,2 diol (slow or weak, slow), butane 2,3 diol (weak, slow and variable) and hexadecane (slow and variable) are assimilated; no growth occurs on inulin, methanol or saccharate. Ethylamine hydrochloride, L-lysine, cadaverine dihydrochloride and glucosamine (as nitrogen source) are assimilated; potassium nitrate, sodium nitrite, creatine, creatinine and imidazole are not assimilated. The formation of amyloid material is negative. Growth in vitamin-free medium is negative. Growth occurs at $25{ }^{\circ} \mathrm{C}$; it is weak and variable at $30{ }^{\circ} \mathrm{C}$ and negative at $35{ }^{\circ} \mathrm{C}$. Growth is present on $50 \%$ $(\mathrm{w} / \mathrm{w})$ glucose-yeast extract agar, with $10 \% \mathrm{NaCl}$ and with $16 \% \mathrm{NaCl}$ (weak). No growth occurs on $60 \%(\mathrm{w} / \mathrm{w})$ glucose-yeast extract agar or with $1 \%$ acetic acid. Growth with $0.1 \%$ cycloheximide is positive. Urea hydrolysis and colour reaction with diazonium blue $\mathrm{B}$ are negative.

The type and isotype strains were recovered from mouldy honeycomb in Hungary, and are maintained respectively as NCAIM Y. $01848^{\mathrm{T}}\left(=\right.$ CBS $10922^{\mathrm{T}}=$ NRRL Y $\left.-48475^{\mathrm{T}}\right)$ and NCAIM Y.01849 ${ }^{\mathrm{IT}}\left(=\mathrm{CBS} 10923^{\mathrm{IT}}=\right.$ NRRL Y-48476 $\left.{ }^{\mathrm{IT}}\right)$ in the National Collection of Agricultural and Industrial Microorganisms in Budapest (Hungary). NCAIM Y.01848 ${ }^{\mathrm{T}}$ and NCAIM Y.01849 ${ }^{\mathrm{IT}}$ represent opposite mating types. 


\section{Acknowledgements}

This research was partly supported by the Bolyai János Research Scholarship of the Hungarian Academy of Sciences.

\section{References}

Altschul, S. F., Madden, T. L., Schäffer, A. A., Zhang, J., Zhang, Z., Miller, W. \& Lipman, D. J. (1997). Gapped BLAST and PSI-BLAST: a new generation of protein database search programs. Nucleic Acids Res 25, 3389-3402.

Benny, G. L. \& Kimbrough, J. W. (1980). A synopsis of the orders and families of plectomycetes with keys to genera. Mycotaxon 12, 1-91.

Carreiro, S. C., Pagnocca, F. C., Bacci, M., Jr, Lachance, M.-A., Bueno, O. C., Hebling, M. J. A., Ruivo, C. C. C. \& Rosa, C. A. (2004). Sympodiomyces attinorum sp. nov., a yeast species associated with nests of the leaf-cutting ant Atta sexdens. Int J Syst Evol Microbiol 54, 1891-1894.

Fell, J. W. \& Statzell, A. C. (1971). Sympodiomyces gen. n., a yeast-like organism from southern marine waters. Antonie van Leeuwenhoek 37, 359-367.

Hauerslev, K. (1987). Three new or rare resupinate fungi from Denmark. Friesia 11, 281-286.

Jackson, H. S. (1947). Trichomonascus, a new genus among simple ascomycetes. Mycologia 39, 709-715.

Kurtzman, C. P. (2004). Trichomonascus petasosporus sp. nov. and Sympodiomyces indianaensis sp. nov., two new members of the Saccharomycetales. Antonie van Leeuwenhoek 85, 297-304.

Kurtzman, C. P. (2007). Blastobotrys americana sp. nov., Blastobotrys illinoisensis sp. nov., Blastobotrys malaysiensis sp. nov., Blastobotrys muscicola sp. nov., Blastobotrys peoriensis sp. nov. and Blastobotrys raffinosifermentans sp. nov., novel anamorphic yeast species. Int J Syst Evol Microbiol 57, 1154-1162.

Kurtzman, C. P. \& Robnett, C. J. (1998). Identification and phylogeny of ascomycetous yeasts from analysis of nuclear large subunit (26S) ribosomal DNA partial sequences. Antonie van Leeuwenhoek 73, 331371.

Kurtzman, C. P. \& Robnett, C. J. (2007). Multigene phylogenetic analysis of the Trichomonascus, Wickerhamiella and Zygoascus yeast clades, and the proposal of Sugiyamaella gen. nov. and 14 new species combinations. FEMS Yeast Res 7, 141-151.

Malloch, D. \& de Hoog, G. S. (1998). Endomycete-like genera of mycoparasitic fungi. In The Yeasts, a Taxonomic Study, 4th edn, pp. 197-200. Edited by C. P. Kurtzman \& J. W. Fell. Amsterdam: Elsevier.

Middelhoven, W. J. \& Kurtzman, C. P. (2007). Four novel yeasts from decaying organic matter: Blastobotrys robertii sp. nov., Candida cretensis sp. nov., Candida scorzettiae sp. nov. and Candida vadensis sp. nov. Antonie van Leeuwenhoek 92, 233-244.

Saitou, N. \& Nei, M. (1987). The neighbor-joining method: a new method for reconstructing phylogenetic trees. Mol Biol Evol 4, 406425.

Smith, M. Th., van der Walt, J. P. \& Johannsen, E. (1976). The genus Stephanoascus gen. nov. (Ascoideaceae). Antonie van Leeuwenhoek 42, 119-127.

Statzell-Tallman, A. \& Fell, J. W. (1998). Sympodiomyces Fell \& Statzell. In The Yeasts, a Taxonomic Study, 4th edn, pp. 603-604. Edited by C. P. Kurtzman \& J. W. Fell. Amsterdam: Elsevier.

Thompson, J. D., Gibson, T. J., Plewniak, F., Jeanmougin, F. \& Higgins, D. G. (1997). The CLUSTAL_X windows interface: flexible strategies for multiple sequence alignment aided by quality analysis tools. Nucleic Acids Res 25, 4876-4882.

van der Walt, J. P., Smith, M. Th. \& Yamada, Y. (1990). Arxula gen. nov. (Candidaceae), a new anamorphic, arthroconidial yeast genus. Antonie van Leeuwenhoek 57, 59-61.

von Klopotek, A. (1967). Blastobotrys nivea gen. nov., sp. nov. Arch Mikrobiol 58, 92-96 (in German).

Yarrow, D. (1998). Methods for the isolation, maintenance and identification of yeasts. In The Yeasts, a Taxonomic Study, 4th edn, pp. 77-100. Edited by C. P. Kurtzman \& J. W. Fell. Amsterdam: Elsevier. 